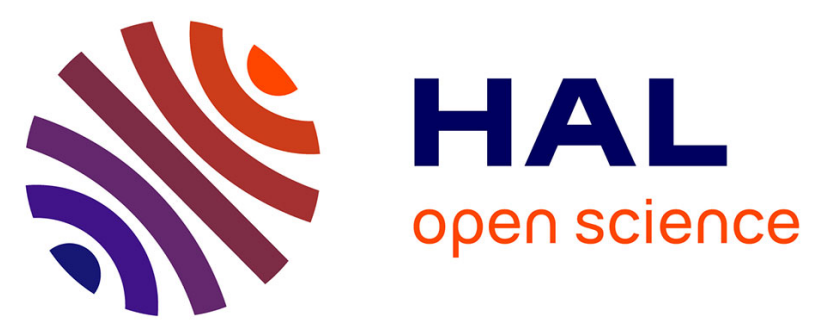

\title{
The 22q11 PRODH/DGCR6 deletion is frequent in hyperprolinemic subjects but is not a strong risk factor for ASD.
}

Anne-Claire Richard, Anne Rovelet-Lecrux, Elsa Delaby, Camille Charbonnier, Bhooma Thiruvahindrapuram, Eli Hatchwell, Peggy S Eis, Alexandra Afenjar, Brigitte Gilbert Dussardier, Stephen W Scherer, et al.

\section{To cite this version:}

Anne-Claire Richard, Anne Rovelet-Lecrux, Elsa Delaby, Camille Charbonnier, Bhooma Thiruvahindrapuram, et al.. The 22q11 PRODH/DGCR6 deletion is frequent in hyperprolinemic subjects but is not a strong risk factor for ASD.. American Journal of Medical Genetics Part B: Neuropsychiatric Genetics, 2016, 171B (3), pp.377-82. 10.1002/ajmg.b.32416 . inserm-01289348

\section{HAL Id: inserm-01289348 https://www.hal.inserm.fr/inserm-01289348}

Submitted on 16 Mar 2016

HAL is a multi-disciplinary open access archive for the deposit and dissemination of scientific research documents, whether they are published or not. The documents may come from teaching and research institutions in France or abroad, or from public or private research centers.
L'archive ouverte pluridisciplinaire HAL, est destinée au dépôt et à la diffusion de documents scientifiques de niveau recherche, publiés ou non, émanant des établissements d'enseignement et de recherche français ou étrangers, des laboratoires publics ou privés. 


\title{
The 22q11 PRODH/DGCR6 deletion is frequent in hyperprolinemic subjects but is not a strong risk factor for ASD
}

Anne Claire Richard ${ }^{1}$, Anne Rovelet-Lecrux ${ }^{1}$, Elsa Delaby ${ }^{2,3,4}$, Camille Charbonnier ${ }^{1}$, Bhooma Thiruvahindrapuram ${ }^{5}$, Eli Hatchwell ${ }^{6}$, Peggy S. Eis $^{6}$, Alexandra Afenjar ${ }^{7}$, Brigitte Gilbert Dussardier ${ }^{8}$, Stephen W. Scherer ${ }^{5,9}$, Catalina Betancur ${ }^{2,3,4}$, Dominique Campion ${ }^{1,10 *}$

${ }^{1}$ Inserm U1079, Institute for Research and Innovation in Biomedicine, University of Rouen, France

${ }^{2}$ Inserm U1130, Neuroscience Paris Seine, Paris, France

${ }^{3}$ CNRS UMR 8246, Neuroscience Paris Seine, Paris, France

${ }^{4}$ Sorbonne Universités, UPMC Univ Paris 6, Institut de Biologie Paris-Seine, Paris, France

${ }^{5}$ The Centre for Applied Genomics, and Program in Genetics and Genome Biology, the Hospital for Sick

Children, Toronto, Ontario, Canada

${ }^{6}$ Population Diagnostics, Inc., Melville, New York, USA

${ }^{7}$ Unité de neuropédiatrie et pathologie du développement, CHU Paris Est - Hôpital d'Enfants Armand-

Trousseau, Paris, France

${ }^{8}$ Service de génétique médicale, $\mathrm{CHU}$ de Poitiers, France

${ }^{9}$ McLaughlin Centre and Department of Molecular Genetics, University of Toronto, Toronto, Ontario, Canada

${ }^{10}$ Centre Hospitalier du Rouvray, Sotteville-lès-Rouen, France

*Correspondence to: Dominique Campion, Inserm UMR1079, Faculté de Médecine, 22 boulevard Gambetta, 76183 Rouen, France. Email: dominique.campion@univ-rouen.fr

\begin{abstract}
The proline dehydrogenase (PRODH) gene maps to $22 q 11.2$ in the region deleted in the velo-cardiofacial syndrome (VCFS). A moderate to severe reduction ( $>50 \%$ ) in PRODH activity resulting from recessive deletions and/or missense mutations has been shown to cause type 1 hyperprolinemia (HPI). Autistic features have been reported as a common clinical manifestation of HPI. Here we studied the frequency of a recurrent small 22q11.2 deletion encompassing $P R O D H$ and the neighboring DGCR6 gene in three case-control studies, one comprising HPI patients $(n=83)$, and the other two comprising autism spectrum disorder (ASD) patients (total of $n=2800$ ), analyzed with highresolution microarrays. We found that the $P R O D H$ deletion is a strong risk factor for HPI $(O R=50.7$; $95 \% \mathrm{Cl}=7.5-2147)$ but not for ASD $(p=0.4, O R=0.6-3.3)$. This result indicates either that the suggested association between ASD and HPI is spurious and results from a bias leading to the preferential inclusion of ASD patients in HPI series, or that HPI is present in only a very small subset of ASD patients. In this latter case, a very large sample size would be required to detect an association between the PRODH deletion and ASD in a case-control study.
\end{abstract}

Key words: Proline dehydrogenase, copy number variant, 22q11.2 deletion, autism, hyperprolinemia 


\section{INTRODUCTION}

The $P R O D H$ gene encodes proline dehydrogenase, a mitochondrial enzyme that catalyzes the conversion of proline into $\Delta 1$-pyrroline-5-carboxylate (P5C). It is located in the $22 \mathrm{q} 11.2$ chromosomal region, near the segmental duplication that defines the proximal boundary of the $3 \mathrm{Mb}$ segment commonly deleted in velo-cardio-facial syndrome (VCFS) [Bittel et al. 2009]. Typical 22q11.2 deletions in VCFS patients include $\sim 30$ genes. We previously identified a smaller 22q11.2 deletion encompassing only $P R O D H$ and the neighboring DGCR6 gene in a schizoaffective patient without VCFS clinical features [Jacquet et al. 2002] (Figure S1). The frequency of this copy number variant (CNV) was subsequently reported to be $1 / 250$ individuals in a Japanese population, making it 10 -fold more prevalent than the VCFS-associated 22q11.2 deletion [Ohtsuki et al. 2004]. The reciprocal duplication was even more common, with an estimated frequency of 2.5/100 individuals [Guilmatre et al. 2010]. The PRODH/DGCR6 deletion is frequently observed in patients with type 1 hyperprolinemia (HPI) [Jacquet et al. 2003; Guilmatre et al. 2010]. Since HPI is a recessive condition, the $P R O D H$ deletion must be combined with another hit (usually a missense mutation reducing enzymatic activity) on the second allele to cause an increase in plasma proline levels [Guilmatre et al. 2010]. The clinical phenotype of HPI is still not well characterized. While some HPI subjects have intellectual disability, seizures, language delay, autistic features, schizophrenia or bipolar disorder, others are asymptomatic [Afenjar et al. 2007; Di Rosa et al. 2008; Guilmatre et al. 2010; Di Rosa et al. 2014]. In particular, autism spectrum disorder (ASD) has been reported as a prevalent clinical feature of HPI, although the diagnosis often does not rely on formal criteria [Afenjar et al. 2007; Di Rosa et al. 2008; Guilmatre et al. 2010]. The involvement of HPI in ASD determinism is supported by the fact that PRODH deficiency in mice results in increased neurotransmitter release at glutamatergic synapses [Paterlini et al. 2005] and glutamate is possibly involved in ASD pathology [reviewed in Choudhury et al. 2012].

Thus, the question arises whether the PRODH/DGCR6 deletion is associated with ASD. Supporting a putative role as a risk factor, Guilmatre et al. [2009] reported a significant association of this deletion with ASD in a small sample (9/260 ASD cases vs. $1 / 236$ controls, $p=0.02$ Fisher exact test, $\mathrm{OR}=8.4 ; 95 \% \mathrm{Cl}=1.15-370.2)$. Due to its combined frequency $>1 \%$ in the general population, PRODH/DGCR6 deletions and reciprocal duplications were not reported in most of the recently published large CNV case-control studies in ASD, which focused on rare variants, usually with a frequency <1\% [Pinto et al. 2010; Sanders et al. 2011; Gai et al. 2012; Girirajan et al. 2013; Pinto et al. 2014]. Moreover, since these studies used different microarray platforms, this CNV might have been missed due to insufficient probe coverage or differences in CNV-calling algorithms. To further clarify the implication of the PRODH/DGCR6 CNV in ASD risk we examined its frequency in three case/control studies, one including $\mathrm{HPI}$ subjects and two including ASD patients, using data generated by both CGH and SNP array platforms. 


\section{PATIENTS AND METHODS}

\section{HPI study}

To constitute the HPI cohort, we reviewed all HPI cases (with fasting plasma proline $>400 \mu \mathrm{mol} / \mathrm{L}$ ) in which a genetic analysis of the $P R O D H$ gene had previously been undertaken by our laboratory. Only cases where the phase of $P R O D H$ mutations was unambiguously established were retained $(n=83)$. VCFS patients were not included. The mean age of the patients was 9.6 years ( $S D=2.8$, range $=2-42$ ). All cases except five were Caucasian. The control cohort consisted of 236 adult healthy Caucasian subjects with normal plasma proline level [Guilmatre et al. 2009]. This study was approved by the Rouen University Hospital ethics committee and all patients or their parents and controls signed a written informed consent. The DNA samples were derived from whole blood. CNV analysis was performed by using the Human High-Resolution Discovery Microarray Kit 1x1 M (design ID 021529, Agilent Technologies, Santa Clara, CA, USA) following standard protocols. A non-commercial genomic DNA pool of 10 control individuals was used as a reference sample. Hybridization results were extracted with the Feature Extraction software v.10.5.1.1 (Agilent Technologies) and analyzed using the DNA Analytics software v.4.0.81 (Agilent Technologies). The data were processed by the ADM-2 algorithm, with the threshold set at 6.0 SD. CNVs were confirmed by quantitative multiplex PCR of short fluorescent fragments (QMPSF) as previously described [Guilmatre et al. 2009]. Sanger sequencing of the $P R O D H$ gene was performed on an $A B I$ prism 3100 automated sequencer (Applied Biosystems, Foster City, CA, USA) using previously described primers [Raux et al. 2007].

\section{ASD sample 1}

The subjects analyzed by the international consortium Autism Genome Project (AGP) included 2,446 ASD unrelated cases (2,114 males and 332 females) and 4,768 controls (2,022 males and 2,746 females) [Pinto et al. 2014]. Affected individuals were assessed using the Autism Diagnostic Interview-Revised (ADI-R) and/or the Autism Diagnostic Observation Schedule (ADOS). Unrelated adult control subjects were assembled from three studies in which individuals had no obvious psychiatric history: the Study of Addiction Genetics and Environment [Bierut et al. 2010], the Ontario Colorectal Cancer Case-Control Study [Figueiredo et al. 2011], and Health, Aging, and Body Composition [Fox et al. 2012]. The ASD cases and comparison subjects were not matched for age. The Autism Genome Project cases included both children and adults, whereas the control subjects where all adults, reflecting the fact that they were not recruited specifically for the ASD study. Given that this is a genetic association study, the age of the subjects should not have any effect on the results.

DNA samples were derived from whole blood or cell lines. All samples were genotyped using Illumina 1M single or duo microarrays (Illumina, San Diego, CA, USA) and analyzed with the same quality-control procedures and CNV analysis pipeline. CNVs were detected using a multiple-algorithm approach including QuantiSNP [Colella et al. 2007], iPattern [Pinto et al. 2011], and PennCNV [Wang et al. 2007]. CNVs spanning less than five consecutive probes or less than $5 \mathrm{~kb}$, or with low 
confidence score were excluded. For a detailed description of quality control procedures, see Pinto et al. [2010]. Ancestry was inferred from genotyping data; among the cases, 2,147 (87.8\%) were of European ancestry; in the control cohort, 2,640 (55.4\%) were of European ancestry. Informed consent was obtained from all participants or their parents, and all procedures followed were in accordance with the ethical standards on human experimentation of the participating sites.

\section{ASD sample 2}

This study included 676 unrelated ASD cases and 1005 controls that passed array quality control. The ASD samples (560 males and 116 females) came from three Canadian sites: Hospital for Sick Children in Toronto, Ontario; McMaster University, Hamilton, Ontario; and Memorial University of Newfoundland, St. John's, Newfoundland [Prasad et al. 2012]. All the cases met the criteria for autism on one or both diagnostic measures - ADI-R and ADOS. CNV analysis was performed on genomic DNA derived from blood or lymphoblastoid cell lines. Data for the control cohort of 1005 DNA samples were provided by Population Diagnostics, Inc. (Melville, NY, USA) [Prasad et al. 2012]. Briefly, the cohort (referred to as PDx controls) comprised reportedly healthy donors of European ancestry ( 500 females and 505 males, $>45$ years of age) with no known history of disease, including psychiatric disorders. All donors were consented and deidentified via a protocol approved by the institutional review board. The DNA samples were all derived from whole blood. All case and control samples were run on the Agilent 1M CGH array (Agilent Technologies, Santa Clara, CA, USA) and used CNV-calling methods as previously described [Prasad et al. 2012]. The reference DNA for cases was a pool of 50 sex-matched European ancestry control samples; for controls, the same sex-matched sample (one female or one male) was used. Ancestry analysis in 615 out of 676 cases with SNP microarray data available indicated that 505 cases were of European ancestry. Of the 676 ASD cases studied with Agilent 1M CGH arrays, 322 were also included in the AGP and were studied with SNP arrays [Pinto et al. 2010; Pinto et al. 2014], thus allowing a direct comparison between the two microarray platforms.

\section{RESULTS}

\section{HPI cohort}

Among the $83 \mathrm{HPI}$ subjects, 15 (18\%) carried the PRODH/DGCR6 deletion (Table I). In four patients the deletion was homozygous. CGH array analysis indicated that $P R O D H$ deletions and duplications had similar breakpoints, with an approximate size of $120 \mathrm{~kb}$ (Figure S2). The CNV is immediately preceded by a $237 \mathrm{~kb}$-long segmental duplication (also termed low-copy repeat, LCR) region, referred to as LCR22-2, which corresponds to the proximal breakpoint of the classical VCFS deletions (Figure S1). Of note, the presence of this LCR is characterized by a gap in probe coverage on the CGH array, which makes the exact determination of the breakpoint uncertain. The clinical phenotype of HPI subjects included ASD in 7/15 subjects (Table I). In the control group (Table II), only one subject carried the PRODH/DGCR6 deletion. His plasma proline level $(337 \mu \mathrm{mol} / \mathrm{L})$ was at the upper limit of 
normal values and his complete $P R O D H$ genotype was Del/Q19P+T275N. The frequency of deletion carriers (either at the homozygous or heterozygous state) significantly differed between cases and controls ( $p=8.6 \times 10^{-9}$, Fisher exact test), and carrying at least one deleted allele was a strong risk factor for $\mathrm{HPI}(\mathrm{OR}=50.7 ; 95 \% \mathrm{Cl}=7.5-2,147)$.

\section{ASD samples}

In ASD study 1 (AGP), the SNP array revealed that 11/2,446 ASD subjects carried the deletion (10 males, 1 female), compared to 15/4,768 control individuals ( 8 males, 7 females) ( $p=0.4$, OR $=0.6$ 3.3) (Table II). Two ASD cases with a larger deletion corresponding to VCFS were not included in these counts. In ASD study 2, array CGH analysis identified 6 PRODH/DGCR6 deletion carriers among the 676 ASD individuals (4 deletions in 354 unique individuals not included in the AGP sample), and 9 deletion carriers among the 1005 control individuals $(p=1 ; O R=0.3-3.2$, Fisher exact test). Analyses restricted to European cases and controls yielded similar negative findings (Table II). Genotype calls were concordant among the 322 ASD patients assessed on both Agilent 1M CGH and SNP array platforms. The two deletion carriers present in this subsample were found in both analyses, indicating that two microarray platforms seem equally suitable to detect the PRODH/DGCR6 deletion.

There were 45 duplications in the AGP cases (1.8\%, 41 males, 4 females; 41 in Europeans) excluding 5 duplications of the VCFS region - and 102 in controls (2.1\%, 45 males, 57 females; 57 in Europeans, 11 mixed ethnicity, 34 other ethnicity). The overall frequency of the duplication in controls and ASD patients was consistent with that previously reported (2.5\%) [Guilmatre et al. 2010], and is also comparable to what was observed in the PDx control cohort (18 duplications corresponding to $1.8 \%$ frequency, 7 males, 11 females; all European).

\section{DISCUSSION}

Despite a possible role of hyperprolinemia in ASD, and the strong involvement of the PRODH/DGCR6 deletion in the genetic determinism of hyperprolinemia, we did not find any significant association between this deletion and ASD in two large case/control samples.

This negative finding could indicate that the suggested enrichment of ASD cases in HPI patients is spurious and reflects an inclusion bias (i.e., clinical geneticists preferentially refer HPI patients with an ASD diagnosis for genetic analysis). A limitation of this study concerning HPI patients is that we relied on the clinical description of patients made by the clinician who referred blood samples to our laboratory and that structured interviews allowing a formal diagnosis were rarely used. Alternatively, our results could be explained by the low prevalence of HPI among ASD patients. For example, we recently measured plasma proline level in a consecutive series of 230 ASD patients (unpublished data) and found only one HPI case $(95 \% \mathrm{Cl}[0.028-0.0002])$. Thus, only approximately one HPI in 230 ASD cases might contribute to increase the load of PRODH/DGCR6 deletions compared to the baseline. Based on an estimated frequency of HPI among ASD subjects of $1 / 230$ and assuming that 
only $18 \%$ of these HPI subjects will be expected to harbor the PRODH/DGCR6 deletion (this study), the deletion frequency would be expected to increase from $0.4 \%$ (i.e., the average frequency observed in the two control samples) to $0.48 \%$. A sample size of about 107,000 patients and a similar number of controls would be required to reach an $80 \%$ chance of detecting such an association between ASD and the PRODH/DGCR6 deletion at the 5\% level (http://www.stat.ubc.ca/ rollin/stats/ ssize/b2.html). At best, if we consider the upper limit of the $95 \%$ confidence interval for the frequency of $\mathrm{HPI}$ among ASD, $2.8 \%$, the deletion frequency would be expected to increase from $0.4 \%$ in controls to $0.9 \%$ in ASD cases, which would require a sample size of about 4,000 each. We conclude that the involvement of HPI in the determinism of ASD remains controversial and is not supported by this CNV study. Given the extreme genetic heterogeneity of ASD and the fact that all disease-causing variants identified to date are very rare [Betancur 2011], the risk conferred by HPI, if any, is likely to be small. To definitely settle this issue there is an urgent need to measure fasting proline levels in large unbiased cohorts of ASD subjects and controls.

\section{ACKNOWLEDGEMENTS}

The authors thank the study participants and the Autism Genome Project (AGP) Consortium. The authors declare no conflict of interest.

\section{REFERENCES}

Afenjar A, Moutard ML, Doummar D, Guet A, Rabier D, Vermersch Al, Mignot C, Burglen L, Heron D, Thioulouse E, de Villemeur TB, Campion D, Rodriguez D. 2007. Early neurological phenotype in 4 children with biallelic PRODH mutations. Brain Dev 29:547-552.

Betancur C. 2011. Etiological heterogeneity in autism spectrum disorders: more than 100 genetic and genomic disorders and still counting. Brain Res 1380:42-77.

Bierut L, Agrawal A, Bucholz KK, Doheny KF, Laurie C, Pugh E, Fisher S, Fox L, Howells W, Bertelsen S, Hinrichs AL, Almasy L, Breslau N, Culverhouse RC, Dick DM, Edenberg HJ, Foroud T, Grucza RA, Hatsukami D, Hesselbrock V, Johnson EO, Kramer J, Krueger RF, Kuperman S, Lynskey M, Mann K, Neuman RJ, Nothen MM, Nurnberger JI, Jr., Porjesz B, Ridinger M, Saccone NL, Saccone SF, Schuckit MA, Tischfield JA, Wang JC, Rietschel M, Goate AM, Rice JP, Gene EASC. 2010. A genome-wide association study of alcohol dependence. Proc Natl Acad Sci USA 107:5082-5087.

Bittel DC, Yu S, Newkirk H, Kibiryeva N, Holt A, 3rd, Butler MG, Cooley LD. 2009. Refining the 22q11.2 deletion breakpoints in DiGeorge syndrome by aCGH. Cytogenet Genome Res 124:113-120.

Choudhury PR, Lahiri S, Rajamma U. 2012. Glutamate mediated signaling in the pathophysiology of autism spectrum disorders. Pharmacol Biochem Behav 100:841-849.

Colella S, Yau C, Taylor JM, Mirza G, Butler H, Clouston P, Bassett AS, Seller A, Holmes CC, Ragoussis J. 2007. QuantiSNP: an Objective Bayes Hidden-Markov Model to detect and accurately map copy number variation using SNP genotyping data. Nucleic Acids Res 35:2013-2025.

Di Rosa G, Nicotera AG, Lenzo P, Spano M, Tortorella G. 2014. Long-term neuropsychiatric follow-up in hyperprolinemia type I. Psychiatr Genet 24:172-175.

Di Rosa G, Pustorino G, Spano M, Campion D, Calabro M, Aguennouz M, Caccamo D, Legallic S, Sgro DL, Bonsignore M, Tortorella G. 2008. Type I hyperprolinemia and proline dehydrogenase (PRODH) mutations in four Italian children with epilepsy and mental retardation. Psychiatr Genet 18:40-42.

Figueiredo JC, Lewinger JP, Song C, Campbell PT, Conti DV, Edlund CK, Duggan DJ, Rangrej J, Lemire M, Hudson T, Zanke B, Cotterchio M, Gallinger S, Jenkins M, Hopper J, Haile R, Newcomb P, Potter J, Baron JA, Le Marchand L, Casey G. 2011. Genotype-environment interactions in microsatellite stable/microsatellite instability-low colorectal cancer: results from a genome-wide association study. Cancer Epidemiol Biomarkers Prev 20:758-766. 
Fox CS, Liu Y, White CC, Feitosa M, Smith AV, Heard-Costa N, Lohman K, Consortium G, Consortium M, Consortium G, Johnson AD, Foster MC, Greenawalt DM, Griffin P, Ding J, Newman AB, Tylavsky F, Miljkovic I, Kritchevsky SB, Launer L, Garcia M, Eiriksdottir G, Carr JJ, Gudnason V, Harris TB, Cupples LA, Borecki IB. 2012. Genome-wide association for abdominal subcutaneous and visceral adipose reveals a novel locus for visceral fat in women. PLoS Genet 8:e1002695.

Gai X, Xie HM, Perin JC, Takahashi N, Murphy K, Wenocur AS, D'Arcy M, O'Hara RJ, Goldmuntz E, Grice DE, Shaikh TH, Hakonarson H, Buxbaum JD, Elia J, White PS. 2012. Rare structural variation of synapse and neurotransmission genes in autism. Mol Psychiatry 17:402-411.

Girirajan S, Dennis MY, Baker C, Malig M, Coe BP, Campbell CD, Mark K, Vu TH, Alkan C, Cheng Z, Biesecker LG, Bernier R, Eichler EE. 2013. Refinement and discovery of new hotspots of copy-number variation associated with autism spectrum disorder. Am J Hum Genet 92:221-237.

Guilmatre A, Dubourg C, Mosca AL, Legallic S, Goldenberg A, Drouin-Garraud V, Layet V, Rosier A, Briault S, Bonnet-Brilhault F, Laumonnier F, Odent S, Le Vacon G, Joly-Helas G, David V, Bendavid C, Pinoit JM, Henry C, Impallomeni C, Germano E, Tortorella G, Di Rosa G, Barthelemy C, Andres C, Faivre L, Frebourg T, Saugier Veber P, Campion D. 2009. Recurrent rearrangements in synaptic and neurodevelopmental genes and shared biologic pathways in schizophrenia, autism, and mental retardation. Arch Gen Psychiatry 66:947956.

Guilmatre A, Legallic S, Steel G, Willis A, Di Rosa G, Goldenberg A, Drouin-Garraud V, Guet A, Mignot C, Des Portes V, Valayannopoulos V, Van Maldergem L, Hoffman JD, Izzi C, Espil-Taris C, Orcesi S, Bonafe L, Le Galloudec E, Maurey H, loos C, Afenjar A, Blanchet P, Echenne B, Roubertie A, Frebourg T, Valle D, Campion D. 2010. Type I hyperprolinemia: genotype/phenotype correlations. Hum Mutat 31:961-965.

Jacquet H, Berthelot J, Bonnemains C, Simard G, Saugier-Veber P, Raux G, Campion D, Bonneau D, Frebourg T. 2003. The severe form of type I hyperprolinaemia results from homozygous inactivation of the PRODH gene. J Med Genet 40:e7.

Jacquet H, Raux G, Thibaut F, Hecketsweiler B, Houy E, Demilly C, Haouzir S, Allio G, Fouldrin G, Drouin V, Bou J, Petit M, Campion D, Frebourg T. 2002. PRODH mutations and hyperprolinemia in a subset of schizophrenic patients. Hum Mol Genet 11:2243-2249.

Ohtsuki T, Tanaka S, Ishiguro H, Noguchi E, Arinami T, Tanabe E, Yara K, Okubo T, Takahashi S, Matsuura M, Sakai T, Muto M, Kojima T, Matsushima E, Toru M, Inada T. 2004. Failure to find association between PRODH deletion and schizophrenia. Schizophr Res 67:111-113.

Paterlini M, Zakharenko SS, Lai WS, Qin J, Zhang H, Mukai J, Westphal KG, Olivier B, Sulzer D, Pavlidis P, Siegelbaum SA, Karayiorgou M, Gogos JA. 2005. Transcriptional and behavioral interaction between 22q11.2 orthologs modulates schizophrenia-related phenotypes in mice. Nat Neurosci 8:1586-1594.

Pinto D, Darvishi K, Shi X, Rajan D, Rigler D, Fitzgerald T, Lionel AC, Thiruvahindrapuram B, Macdonald JR, Mills R, Prasad A, Noonan K, Gribble S, Prigmore E, Donahoe PK, Smith RS, Park JH, Hurles ME, Carter NP, Lee C, Scherer SW, Feuk L. 2011. Comprehensive assessment of array-based platforms and calling algorithms for detection of copy number variants. Nat Biotechnol 29:512-520.

Pinto D, Delaby E, Merico D, Barbosa M, Merikangas A, Klei L, Thiruvahindrapuram B, Xu X, Ziman R, Wang Z, Vorstman JA, Thompson A, Regan R, Pilorge M, Pellecchia G, Pagnamenta AT, Oliveira B, Marshall CR, Magalhaes TR, Lowe JK, Howe JL, Griswold AJ, Gilbert J, Duketis E, Dombroski BA, De Jonge MV, Cuccaro M, Crawford EL, Correia CT, Conroy J, Conceicao IC, Chiocchetti AG, Casey JP, Cai G, Cabrol C, Bolshakova N, Bacchelli E, Anney R, Gallinger S, Cotterchio M, Casey G, Zwaigenbaum L, Wittemeyer K, Wing K, Wallace S, van Engeland $H$, Tryfon A, Thomson S, Soorya L, Roge B, Roberts W, Poustka F, Mouga S, Minshew N, McInnes LA, McGrew SG, Lord C, Leboyer M, Le Couteur AS, Kolevzon A, Jimenez Gonzalez P, Jacob S, Holt R, Guter S, Green J, Green A, Gillberg C, Fernandez BA, Duque F, Delorme R, Dawson G, Chaste P, Cafe C, Brennan S, Bourgeron T, Bolton PF, Bolte S, Bernier R, Baird G, Bailey AJ, Anagnostou E, Almeida J, Wijsman EM, Vieland VJ, Vicente AM, Schellenberg GD, Pericak-Vance M, Paterson AD, Parr JR, Oliveira G, Nurnberger JI, Monaco AP, Maestrini E, Klauck SM, Hakonarson H, Haines JL, Geschwind DH, Freitag CM, Folstein SE, Ennis S, Coon H, Battaglia A, Szatmari P, Sutcliffe JS, Hallmayer J, Gill M, Cook EH, Buxbaum JD, Devlin B, Gallagher L, Betancur C, Scherer SW. 2014. Convergence of genes and cellular pathways dysregulated in autism spectrum disorders. Am J Hum Genet 94:677-694.

Pinto D, Pagnamenta AT, Klei L, Anney R, Merico D, Regan R, Conroy J, Magalhaes TR, Correia C, Abrahams BS, Almeida J, Bacchelli E, Bader GD, Bailey AJ, Baird G, Battaglia A, Berney T, Bolshakova N, Bolte S, Bolton PF, Bourgeron T, Brennan S, Brian J, Bryson SE, Carson AR, Casallo G, Casey J, Chung BH, Cochrane L, Corsello C, Crawford EL, Crossett A, Cytrynbaum C, Dawson G, de Jonge M, Delorme R, Drmic I, Duketis E, Duque F, Estes A, Farrar P, Fernandez BA, Folstein SE, Fombonne E, Freitag CM, Gilbert J, Gillberg C, Glessner JT, Goldberg J, Green A, Green J, Guter SJ, Hakonarson H, Heron EA, Hill M, Holt R, Howe JL, Hughes G, Hus V, 
Igliozzi R, Kim C, Klauck SM, Kolevzon A, Korvatska O, Kustanovich V, Lajonchere CM, Lamb JA, Laskawiec M, Leboyer M, Le Couteur A, Leventhal BL, Lionel AC, Liu XQ, Lord C, Lotspeich L, Lund SC, Maestrini E, Mahoney W, Mantoulan C, Marshall CR, McConachie H, McDougle CJ, McGrath J, McMahon WM, Merikangas A, Migita O, Minshew NJ, Mirza GK, Munson J, Nelson SF, Noakes C, Noor A, Nygren G, Oliveira G, Papanikolaou K, Parr JR, Parrini B, Paton T, Pickles A, Pilorge M, Piven J, Ponting CP, Posey DJ, Poustka A, Poustka F, Prasad A, Ragoussis J, Renshaw K, Rickaby J, Roberts W, Roeder K, Roge B, Rutter ML, Bierut LJ, Rice JP, Salt J, Sansom K, Sato D, Segurado R, Sequeira AF, Senman L, Shah N, Sheffield VC, Soorya L, Sousa I, Stein O, Sykes N, Stoppioni V, Strawbridge C, Tancredi R, Tansey K, Thiruvahindrapduram B, Thompson AP, Thomson S, Tryfon A, Tsiantis J, Van Engeland H, Vincent JB, Volkmar F, Wallace S, Wang K, Wang Z, Wassink TH, Webber C, Weksberg R, Wing K, Wittemeyer K, Wood S, Wu J, Yaspan BL, Zurawiecki D, Zwaigenbaum L, Buxbaum JD, Cantor RM, Cook EH, Coon H, Cuccaro ML, Devlin B, Ennis S, Gallagher L, Geschwind DH, Gill M, Haines JL, Hallmayer J, Miller J, Monaco AP, Nurnberger JI, Jr., Paterson AD, Pericak-Vance MA, Schellenberg GD, Szatmari P, Vicente AM, Vieland VJ, Wijsman EM, Scherer SW, Sutcliffe JS, Betancur C. 2010. Functional impact of global rare copy number variation in autism spectrum disorders. Nature 466:368-372.

Prasad A, Merico D, Thiruvahindrapuram B, Wei J, Lionel AC, Sato D, Rickaby J, Lu C, Szatmari P, Roberts W, Fernandez BA, Marshall CR, Hatchwell E, Eis PS, Scherer SW. 2012. A discovery resource of rare copy number variations in individuals with autism spectrum disorder. G3 (Bethesda) 2:1665-1685.

Raux G, Bumsel E, Hecketsweiler B, van Amelsvoort T, Zinkstok J, Manouvrier-Hanu S, Fantini C, Breviere GM, Di Rosa G, Pustorino G, Vogels A, Swillen A, Legallic S, Bou J, Opolczynski G, Drouin-Garraud V, Lemarchand M, Philip N, Gerard-Desplanches A, Carlier M, Philippe A, Nolen MC, Heron D, Sarda P, Lacombe D, Coizet C, Alembik Y, Layet V, Afenjar A, Hannequin D, Demily C, Petit M, Thibaut F, Frebourg T, Campion D. 2007. Involvement of hyperprolinemia in cognitive and psychiatric features of the 22q11 deletion syndrome. Hum Mol Genet 16:83-91.

Sanders SJ, Ercan-Sencicek AG, Hus V, Luo R, Murtha MT, Moreno-De-Luca D, Chu SH, Moreau MP, Gupta AR, Thomson SA, Mason CE, Bilguvar K, Celestino-Soper PB, Choi M, Crawford EL, Davis L, Wright NR, Dhodapkar RM, DiCola M, DiLullo NM, Fernandez TV, Fielding-Singh V, Fishman DO, Frahm S, Garagaloyan R, Goh GS, Kammela S, Klei L, Lowe JK, Lund SC, McGrew AD, Meyer KA, Moffat WJ, Murdoch JD, O'Roak BJ, Ober GT, Pottenger RS, Raubeson MJ, Song Y, Wang Q, Yaspan BL, Yu TW, Yurkiewicz IR, Beaudet AL, Cantor RM, Curland M, Grice DE, Gunel M, Lifton RP, Mane SM, Martin DM, Shaw CA, Sheldon M, Tischfield JA, Walsh CA, Morrow EM, Ledbetter DH, Fombonne E, Lord C, Martin CL, Brooks Al, Sutcliffe JS, Cook EH, Jr., Geschwind D, Roeder K, Devlin B, State MW. 2011. Multiple recurrent de novo CNVs, including duplications of the 7q11.23 Williams syndrome region, are strongly associated with autism. Neuron 70:863-885.

Wang K, Li M, Hadley D, Liu R, Glessner J, Grant SF, Hakonarson H, Bucan M. 2007. PennCNV: an integrated hidden Markov model designed for high-resolution copy number variation detection in whole-genome SNP genotyping data. Genome Res 17:1665-1674. 
Table I. Clinical features and genotype at the PRODH locus in HPI subjects.

\begin{tabular}{|c|c|c|c|c|c|}
\hline Subject & Age (y) & Sex & Clinical features & $\begin{array}{l}\text { Plasma proline } \\
(\mu \mathrm{mol} / \mathrm{I})\end{array}$ & Genotype \\
\hline 144 & 42 & $\mathrm{~F}$ & ID, SZ AFF & 538 & del / R453C \\
\hline 45435 & 31 & $\mathrm{~F}$ & ASD & 487 & del / R185W + Q19P \\
\hline TF1 & 4 & M & ID, Epi & 2246 & del / del \\
\hline BP1 & 39 & $\mathrm{~F}$ & $\mathrm{BP}$ & 470 & del / P406L \\
\hline 001 & 2 & $\mathrm{~F}$ & ID, ASD, Epi & $1515-2186$ & del / del \\
\hline 117 & 11 & $\mathrm{~F}$ & ASD & 488 & del / T275N + V427M \\
\hline Si30 & 5 & M & ID, ASD, Epi & $422-1883$ & del / R453C \\
\hline 12363 & 10 & $\mathrm{M}$ & ID & 512 & del / R185W \\
\hline 107 & 14 & $\mathrm{~F}$ & LD & $692-878$ & del / del \\
\hline 105 & 7 & M & ID, ASD & $599-899$ & del / T275N \\
\hline $201 *$ & 13 & M & ID, ASD, Epi & 1008 & del /del \\
\hline $202 *$ & 7 & $\mathrm{~F}$ & Behav D, Epi & 1700 & del / R453C + T466M \\
\hline $203 *$ & 13 & $\mathrm{~F}$ & ID, Behav D & 411 & del / R185W \\
\hline $204^{*}$ & 15 & $\mathrm{~F}$ & ID, Epi & 556 & del / Q19P + R431H \\
\hline $205^{*}$ & 11 & $M$ & ASD & 481 & del / R453C + R185W \\
\hline
\end{tabular}

*Previously unreported. ASD, autism spectrum disorder; Behav D, behavioral disorder (e.g., aggression, hyperactivity); BP, bipolar disorder; Epi, epilepsy; F, female; ID, intellectual disability; LD, learning disability; M, male; SZ AFF, schizoaffective disorder.

Table II. $P R O D H$ deletions in the three cohorts included in this study.

\begin{tabular}{|c|c|c|c|c|c|c|}
\hline Study & Ancestry & Cases & Controls & p-value ${ }^{a}$ & $\begin{array}{l}\text { Odds ratio ( } 95 \% \\
\text { confidence interval) }\end{array}$ & Array platform \\
\hline \multirow[t]{3}{*}{ HPI } & All ancestries & $15 / 83(18 \%)$ & $1 / 236(0.4 \%)$ & $p=8.6 \times 10-9$ & $O R=50.7(7.5-2,147)$ & Agilent 1M CGH array \\
\hline & European & $12 / 78(15 \%)$ & $1 / 236(0.4 \%)$ & $p=2.9 \times 10-7$ & $\mathrm{OR}=42.2(6.0-1,815)$ & \\
\hline & Other & $3 / 5$ & - & & & \\
\hline \multirow[t]{3}{*}{ ASD 1 (AGP) } & All ancestries & $11 / 2,446(0.4 \%)$ & $15 / 4,768(0.3 \%)$ & $p=0.4$ & $\mathrm{OR}=1.4(0.6-3.3)$ & Illumina $1 M$ SNP array \\
\hline & European & $9 / 2,147(0.4 \%)$ & $12 / 2,640(0.5 \%)$ & $p=1$ & $\mathrm{OR}=0.92(0.3-2.39)$ & \\
\hline & Other & $2 / 299(0.7 \%)$ & $3 / 2,128(0.1 \%)$ & & & \\
\hline \multirow[t]{3}{*}{ ASD 2} & All ancestries & $6 / 676^{b, c}(354)(0.9 \%)$ & $9 / 1005$ (0.9\%) & $p=1$ & $\mathrm{OR}=0.99(0.3-3.2)$ & Agilent 1M CGH array \\
\hline & European & $4 / 505(0.8 \%)$ & $9 / 1005(0.9 \%)$ & $p=1$ & $\mathrm{OR}=0.88(0.2-3.2)$ & \\
\hline & Other & $1 / 110(0.9 \%)$ & - & & & \\
\hline
\end{tabular}

${ }^{\mathrm{a}}$ Fisher exact test

${ }^{\mathrm{b}}$ Among the 676 ASD subjects from Canada tested with CGH array, 322 were also tested with Illumina 1M SNP array as part of the AGP study, leaving 354 unique patients. Among these 354 patients, there were 4 deletion carriers (1.1\%).

${ }^{c}$ Ancestry was determined in 615 ASD cases that were genotyped previously with SNP microarrays; no ancestry information was available for the remaining 61 subjects. 


\section{Supplementary online material}

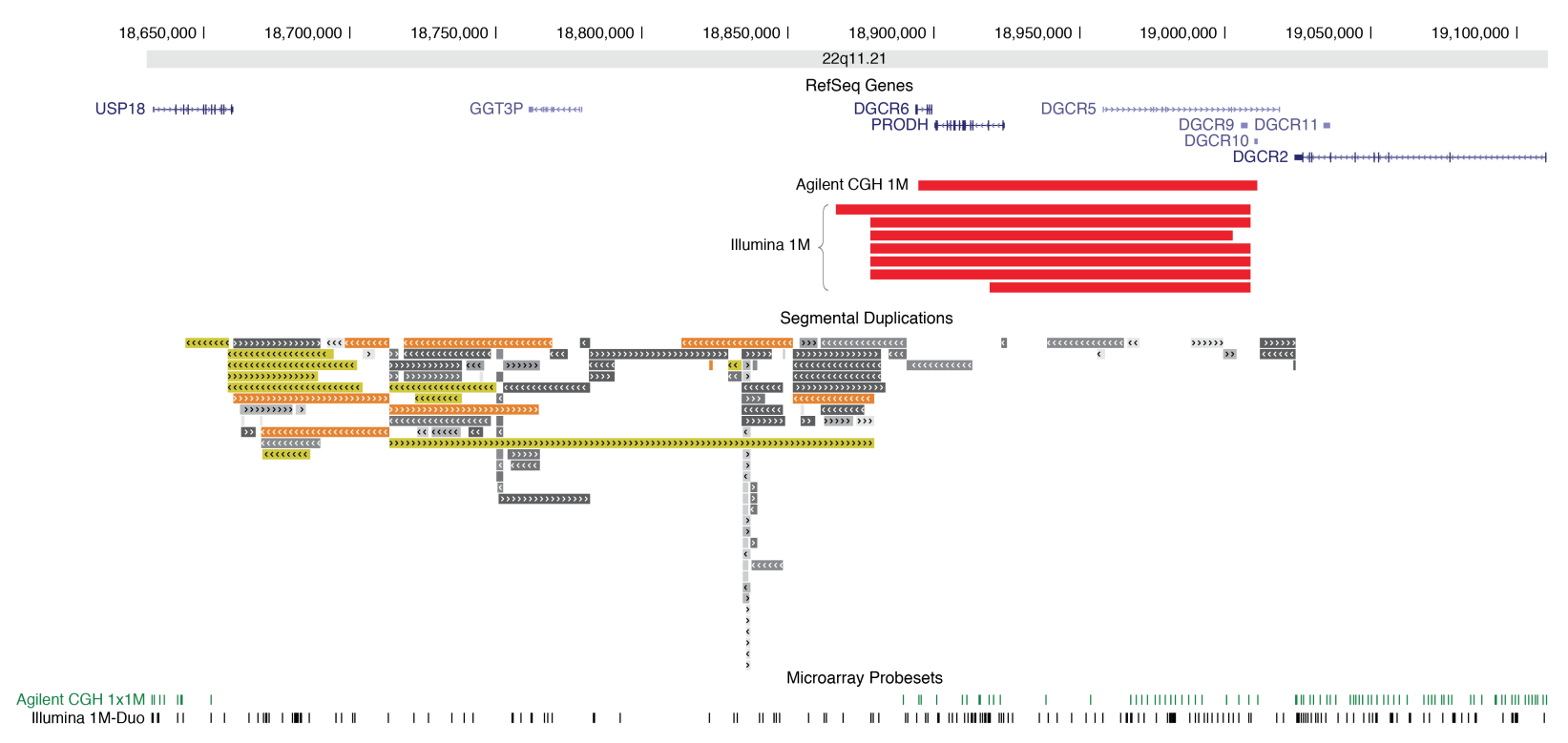

Figure S1. 22q11.21 genomic region involved in the $P R O D H$ recurrent imbalances. Map of the genomic region 18.63-19.11 Mb of chromosome 22 displayed using the UCSC genome browser (GRCh37/hg19). Representative deletions identified with Agilent 1M CGH arrays and with Illumina $1 \mathrm{M}$ SNP arrays are shown in red. Non-coding genes are shown in light blue. The centromeric breakpoint of the PRODH/DGCR6 rearrangement falls within a large region of segmental duplications, which is not covered by Agilent CGH probes. The telomeric breakpoint is located between the noncoding DGCR10 gene and the DGCR2 gene. 


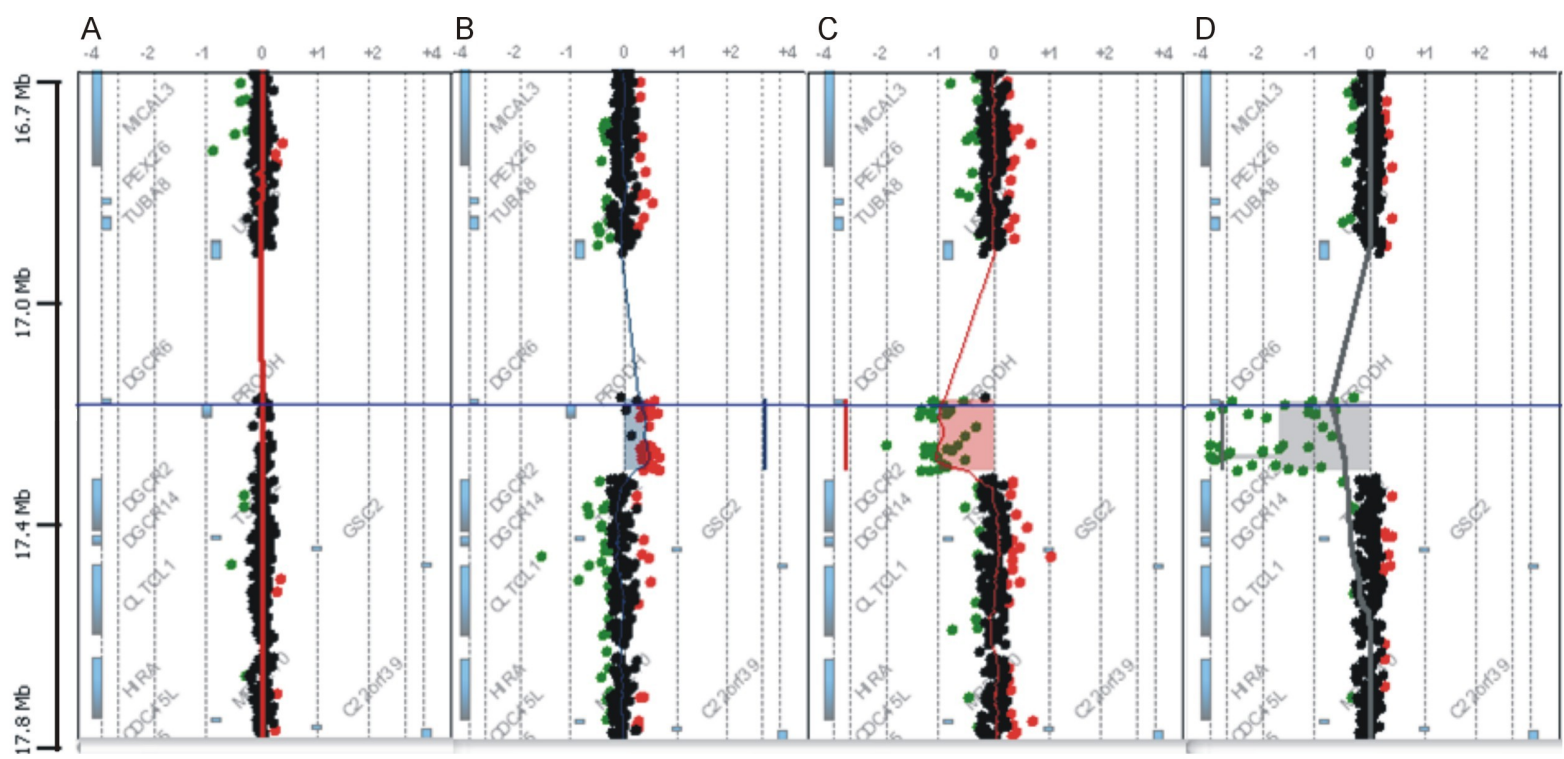

Figure S2. Detailed view of $P R O D H$ rearrangements detected by array-CGH. Note that the region located upstream of $P R O D H$ is not covered by array-CGH probes, due to the presence of an LCR. A. Control individual showing no $P R O D H$ rearrangement. B. Individual carrying a heterozygous duplication of $P R O D H$. C. Individual carrying a heterozygous deletion of $P R O D H$. D. Individual carrying a homozygous deletion of $P R O D H$. 